\title{
Endoscopic Surgery of Nasopharyngeal Angiofibroma
}

\author{
Ressecção Endoscópica de Nasoangiofibroma
}

\author{
Elise Zimmermann*, Ian Selonke**, Fabiano Bleggi Gavazzoni*, Rodrigo Guimarães Pereira **, \\ Silvio Machado***, Tatiane Kimmi Tanamati****.
}

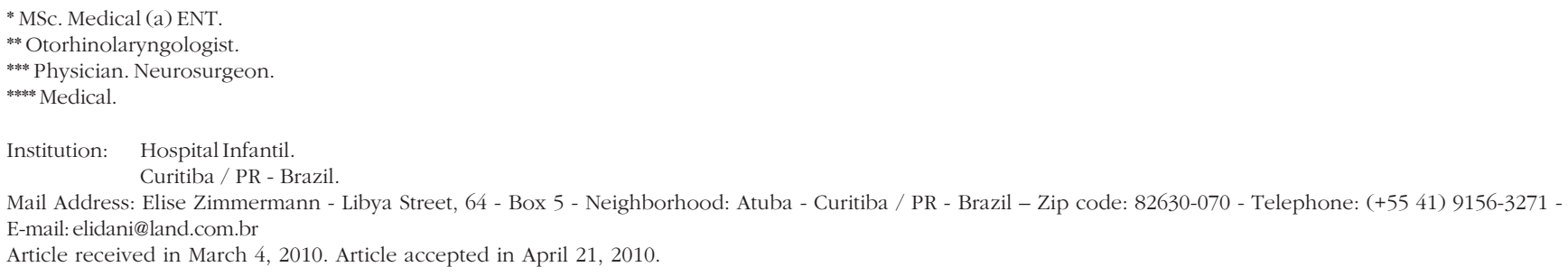

SUMMARY

Introduction:

Juvenile nasopharyngeal angiofibroma (NAJ) is a tumor with vascular component, slow growing, benign but very aggressive because of its local invasiveness. The NAJ is rare, accounting for $0.05 \%$ of all head and neck cancers. The classic triad of epistaxis, unilateral nasal obstruction and a mass in the nasopharynx suggests the diagnosis of NAJ and is then supplemented by imaging. Over the past 10 years the treatment of this disease has been discussed with the aim of designing a management protocol. Currently, surgery appears to be the best treatment of the NAJ. Other methods such as hormone therapy, radiotherapy and chemotherapy treatment modalities are now used occasionally as complementary treatments.

Objective:

Methods:

Results:

Conclusion:

Keywords:

RESUMO

Introdução:

Objetivo:

Método:

Resultados:

Conclusão:

Palavras-chave:
O nasoangiofibroma juvenil (NAJ) é um tumor com componente vascular, de crescimento lento, benigno, porém muito agressivo devido sua invasividade local. O NAJ é de ocorrência rara, respondendo por $0,05 \%$ de todos as neoplasias de cabeça e pescoço. A tríade clássica de epistaxe, obstrução nasal unilateral e uma massa na nasofaringe sugere o diagnóstico de NAJ, sendo então complementado pelo exame de imagem. Nos últimos 10 anos o tratamento desta afecção vem sendo discutida com a finalidade de desenhar um protocolo de manejo. Atualmente a cirurgia parece ser a melhor forma de tratamento dos NAJ. Outros métodos como a hormonioterapia, a radioterapia e a quimioterapia são hoje modalidades terapêuticas usadas ocasionalmente como tratamentos complementares.

Apresentar a casuística desta afecção no Hospital Infantil Pequeno Príncipe entre outubro de 2007 e agosto de 2008 .

Estudo de casos retrospectivo de cinco casos de NAJ submetidos a cirurgia exclusivamente endoscópica com técnica de dois cirurgiões. Classificados entre IIA e IIIA. Todos os pacientes foram submetidos a angiografia com embolização do tumor 3-4 dias antes da cirurgia. Seguimento após a cirurgia para detecção de recidivas.

Houve duas recidivas no seguimento de 2 ano após a cirurgia.

Tendo em vista o curto período de seguimento dos pacientes, houve apenas duas recidivas em um ano. Portanto há necessidade de um maior seguimento para afirmar que essa técnica tem um baixo índice de recidiva, já que a recidiva está provavelmente relacionada à ressecção incompleta do tumor inicial.

angiofibroma, terapêutica, endoscopia, recidiva. 


\section{INTRODUCTION}

The first descriptions of this tumor were made by Hippocrates and date from the 5th century BC, Friedberg was the first to call it angiofibroma in 1940. Other names have been used as a nasopharyngeal fibroma, fibroma of the adolescent and bleeding fibroangioma (1).

The juvenile nasopharyngeal angiofibroma (NAJ) is a tumor with vascular component, slow growing, benign but very aggressive because of its local invasiveness $(2,3,4,5,6,7,8)$.

Occurs almost entirely pre-adolescent and adolescent males, perhaps to respond to androgens $(2,3,4,5,9)$.

The NAJ is rare, accounting for $0.05 \%$ of all head and neck cancers $(2,3,5)$.

Primarily affects young males and today it is the blood group type $\mathrm{O}+$ as a racial marker (10).

The pathogenesis remains controversial, but some theories have been proposed, such as congenital theory, the hormonal, vascular and genetic $(2,3,11)$.

According to ANDRADE et al. tumor selectivity by males may be explained by intranuclear accumulation of androgen receptor and beta-catenin, a coactivator that enhances tumor sensitivity to androgens. The genetic alterations observed more often involve sex chromosomes. Numerous growth factors seem to be implicated in the pathogenesis of tumor. The factor II insulin-like growth is highly expressed, whereas endothelial growth factor (VEGF) and transforming growth factor beta (TGF- $\beta$ ) are released by stromal cells and may influence the growth and vascularization of NAJ (12).

Another recent study of Schlauder et al suggests that the enzyme aromatase is responsible for local conversion of androgens to estrogens, which in turn relates to the role of estrogen receptors in tumor growth (13).

Currently it is believed that the tumor has its origin in the posterolateral wall of the nasal cavity, where the sphenoid process of palatine bone meets the horizontal lamina of the vomer and part of the pterygoid process of sphenoid bone. This junction forms the upper margin of the sphenopalatine where lies the posterior portion of the middle turbinate. From your point of origin then begins its growth beneath the mucosa, extending initially to the posterior nasal cavity and nasopharynx (4.5). Its blood supply is done by the internal maxillary artery, may also be branches of the ipsilateral internal carotid artery $(4,6)$.
The classic triad of epistaxis, unilateral nasal obstruction and a mass in the nasopharynx suggests the diagnosis of NAJ and is then supplemented by imaging tests $(2,4,7,14)$. Computed tomography (CT), magnetic resonance imaging (MRI) and endoscopic examinations are the choice to define the extent and location of the tumor, allowing thus staged. Staging can be done by classifying RADKOwISKi et al, which is based on criteria clínicorradiológicos $(2,3,4,9,11,14,15)$.

Over the past 10 years the treatment of this disease has been discussed with the aim of designing a management protocol. Currently, surgery appears to be the best treatment of the NAJ.Other methods such as hormone therapy, radiotherapy and chemotherapy treatment modalities are now used occasionally as complementary treatments $(9,14,16,17,18)$.

The surgical approach can be made through open, as the transpalatal, transmaxillary, rhinotomy lateral midfacial degloving osteotomy and Le Fort type I (3,6,8,9,16,19). With the advent of minimally invasive techniques, endoscopic surgery has been used to treat NAJ in recent years (19), ideal for tumors confined to the nasopharynx, nasal cavity, and sphenoid sinuses with minimal extension into the pterygopalatine fossa $(2,4,6,8,14,20)$. The first mention of an endoscopic resection date of 1996. Since then a number of cases were reported and all showed that endoscopic resection had a lower morbidity for the early stages of disease (2).

\section{METHOD}

\section{Sample}

A retrospective study of five patients treated with endoscopic surgery only for the period October 2007 to August 2008, at Children's Hospital of Curitiba / PR - Brazil. Since according to their ranking in the various staging systems are tabulated in Table 1.

\section{Technique}

The five patients in this series had treatment by endoscopic nasoangiofibroma being that for such surgery was performed with access through both nostrils, the technique of two surgeons and four hands technique.

We performed a columellar incision intersects (similar to access to the perichondrium of the septum septoplasty) nasoangiofibroma the opposite side. For after septoplasty, a window was made in the cartilaginous septum, enabling 
Table I. Classification in different staging systems.

\begin{tabular}{lcccccccc}
\hline Patients & Andrews & Fisch & Chandler & Sessions & Radkowski & Age & Time & Surgery \\
\hline I. M.G.P & 2 & 2 & 3 & $2 \mathrm{a}$ & $2 \mathrm{a}$ & $14 \mathrm{a} 00 \mathrm{~m}$ & $150 \mathrm{~min}$ & $15 / 10 / 2007$ \\
2. C.E.G & $3 \mathrm{a}$ & 3 & 3 & $2 \mathrm{c}$ & $2 \mathrm{c}$ & $07 \mathrm{a} 02 \mathrm{~m}$ & $310 \mathrm{~min}$ & $05 / 11 / 2007$ \\
3. A.S.M & $3 \mathrm{a}$ & 2 & 3 & $2 \mathrm{c}$ & $2 \mathrm{c}$ & $12 \mathrm{a} 04 \mathrm{~m}$ & $210 \mathrm{~min}$ & $10 / 12 / 2007$ \\
4. C.K & 2 & 2 & 3 & $2 \mathrm{~b}$ & $2 \mathrm{~b}$ & $14 \mathrm{a} 00 \mathrm{~m}$ & $160 \mathrm{~min}$ & $04 / 08 / 2008$ \\
5. F.M & $3 \mathrm{a}$ & 3 & 3 & $2 \mathrm{c}$ & $2 \mathrm{c}$ & $14 \mathrm{a} 04 \mathrm{~m}$ & $110 \mathrm{~min}$ & $11 / 08 / 2008$ \\
\hline
\end{tabular}

you to enter through this passage one or two tools in handling the second surgeon. This deception has brought us more space for access to tumor

All surgeries were performed under general anesthesia, 3-4 days after angiography with embolization of the tumor. During the surgical procedure was used lidocaine $2 \%$ with 1:80,000 adrenaline for infiltration of the lateral wall of the nose and the pterygopalatine fossa through the greater palatine canal. The following solution was used topical 1:4000 adrenaline applied to the nasal mucosa with the aid of cotton swabs to local vasoconstriction, after 10-15 minutes of waiting were removed cottonoids starting the surgical dissection

Due to the size and extent of tumors (see Table 1) we chose to perform an endoscopic medial maxillectomy for tumor in order to work safely to its most lateral extent. We started the first surgical dissection of the tumor through a unciform process incision, anterior and posterior ethmoidectomy with wide exposure of the lamina papyracea and the ethmoid roof. As partial middle turbinectomy and maxillary antrostomy opening wide across posterior fontanelle. These procedures were performed early in the surgery so we could anchor in parameters and well-known landmarks.

After this sequence was performed inferior turbinectomy nearest the insertion of the inferior turbinate to the lateral nasal wall, with subsequent removal of the medial wall of maxilla. So you have access to the wide portion of the maxillary sinus, greatly facilitating the resection of tumors with lateral extension to the infratemporal fossa. We performed the opening of the posterior wall of the maxillary sinus with the aid of a Kerrison forceps delicate.

After exposure of the pterygopalatine and infratemporal fossa was performed under constant traction of the second surgeon, meticulous dissection of the tumor from the surrounding anatomical structures that until identification of the pedicle of the tumor. Who was cauterized with bipolar cautery (Figure 2).

Patients numbers two and three (see table) due to the large size of the tumor was performed in the same section in two parts (split in half). Since the division of the tumor was performed preferably the portion of smaller diameter almost always at the height of the sphenopalatine foramen near the side wall of the nasal cavity and dividing this act was carried out only after control of adjacent structures such as septum, middle turbinate and lateral nasal wall.

Following two years there were two recurrences in patients with just two and three (Figures 1 and 3). However these patients had the following characteristics, the number two is the youngest patient in the study group, which for some authors is related to increased tumor aggressiveness. Patient number three on the eve of surgery hospitalized for respiratory failure and high occupancy by the nose and oropharynx by nasoangiofibroma. He underwent a tracheotomy prior to secure the airway by provisional character. This patient is awaiting examination for staging and subsequent treatment planning.

\section{DISCUSSION}

The nasoangiofibroma, despite their kindness, is highly invasive and has a relapsing and today as elective treatment, surgical resection for all stages (1). Traditionally, the NAJ has been parched by transfacial, transoral or combined craniofacial access. All these procedures lead to changes in the growth of the midface and craniofacial deformities even because of osteotomies performed during these procedures.

Over the years the access route for the treatment of NAJ has been modified with the aim of developing techniques with lower morbidity and lower incidence of recurrence.

Recently, the endoscopic approach has emerged as a surgical option for treating these tumors (4). Initially used to treat diseases such as non-neoplastic polyps and sinus disease, the development of the technique enabled the excision of benign and malignant tumors located more recently (5). The endoscopic resection is best indicated for small tumors confined to the nasopharynx, nasal cavity, ethmoid and sphenoid, and in some cases, tumors with extension into the pterygopalatine fossa (4). In a study 


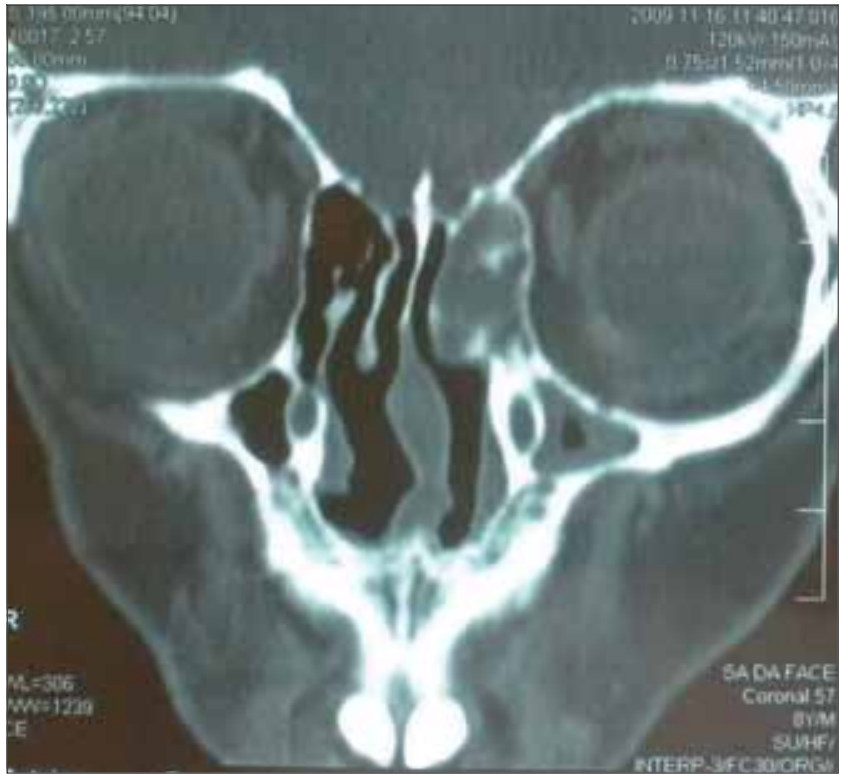

Figure 1. CT of the paranasal sinuses.

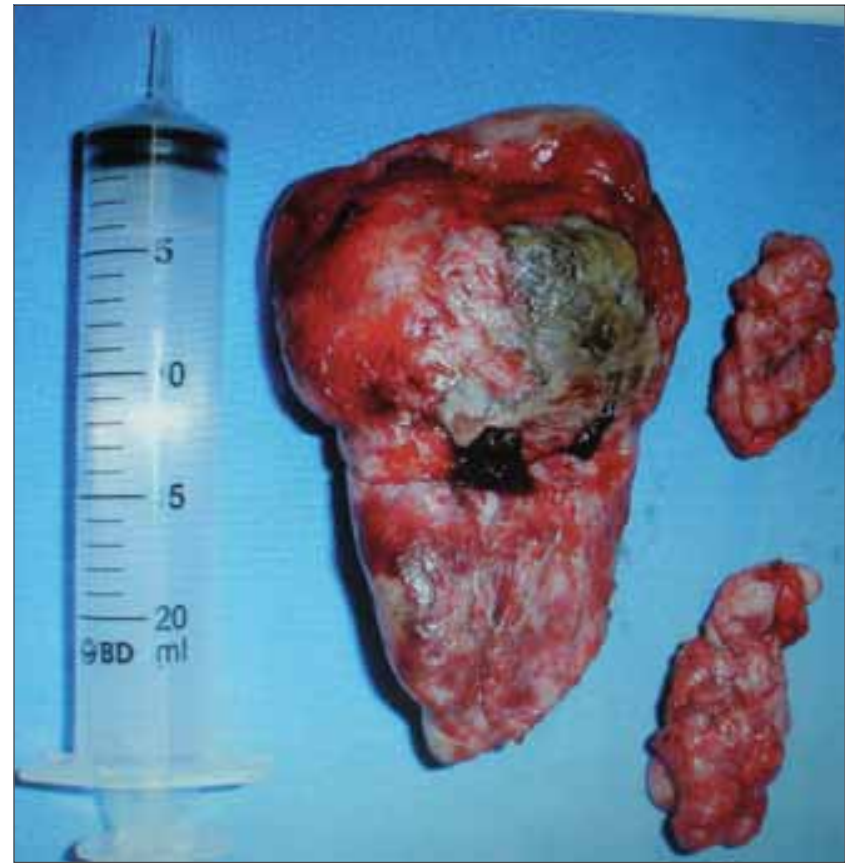

Figure 2. Nnasopharyngeal.

published in a number of patients classified as stage IA and IIB Radkowski, were considered by all authors as appropriate for endoscopic resection (21).

More recently some authors have reported endoscopic resection in stages I through IIIA Radkowski be demonstrated to be safe, effective, decrease blood loss during surgery, as well as lower rates of complications, hospitalization time and rate of tumor recurrence, especially in tumors without intracranial extension $(9,17,22,23)$.

The main advantage of endoscopic surgery is the possibility of obtaining a broad view of the lesion and its anatomic relationship with adjacent structures, promoting more accurate, complete dissection and better control of bleeding $(9,14,23)$. Other advantages include less surgical time, hospitalization, absence of visible scars, avoids complications such as epiphora, dysesthesia, trismus, and craniofacial deformities $(2,5,14,20)$.

The major concern regarding the choice of pathway is the rate of tumor recurrence, which has generated much discussion. Tumor recurrence in the long run has been a frustration. However, recurrence reflects an initial incomplete resection. The recurrence rate of tumors resected endoscopically has been shown to be low. 
recurrence rate of $6.6 \%$ in 15 patients with stages I and II disease. Nicolal et al (9) in their series of 15 patients found only one patient with a residual lesion on follow-up of 24 months. SHePHerd et al (5) in his comparative study between endoscopic and external access of 65 patients, found a rate of $24 \%$ of 49 patients who underwent lateral rhinotomy and five patients undergoing endoscopic surgery no recurrence. KENNEDY et al (24) reported that endoscopic surgery is more appropriate for cases classified in ANDREWs I, II and IIIa selected cases with proven lower rate of bleeding and length of stay.

Perhaps we can attribute the lower rate of recurrence of tumors resected endoscopically because these are the early stages, enabling its complete removal, as for more advanced tumors, such as stage III with greater extension to middle cranial fossa and stage IV, this kind of access is contraindicated $(5,6,21,24)$.

Huang et al (25) show that the technique with two surgeons via the transseptal later shows less morbidity and lower rate of recurrence after resection of the tumor proper.

SAYlam et al (26) in a study of pieces of recurrence found the presence of proliferating cell nuclear antigen (PCNA) and endothelial growth factor (VEGF) and tumor necrosis factor beta (TGF- $\beta$ ) as promoters of angiogenesis and proliferation of NAJ but not yet found a strong relationship to consider these as tumor markers.

The five patients in this study underwent endoscopic resection four days after arteriography with embolization. To remove the tumor in two patients, the tumor section was performed in two halves, the largest of which was removed by transoral route. Maneuver, which provided more space to continue the dissection of the tumor pedicle agreeing with the report by SOLOMON et al (27).

\section{CONCLUSION}

A major advance in the treatment of NAJ was the introduction of endoscopic surgery, because this type of therapy allows complete resection of lesions appropriate with minimal morbidity.

The indication of endoscopic resection is well established for tumors in the earliest stages of disease, as for more advanced tumors as IIIA and IIIB RADKOSKI, has been rarely reported.

The five study patients had stage IIA, IIB or IIC. Due to the fullest extent of the tumor in two patients, the section was performed in two parts of the tumor being removed most of the transoral route and the technique of "adenoidectomy". This technique was reported by Solomon et al. (27), a series of four cases and was effective for complete tumor excision and control of bleeding according to the author. We can see that this technique allows easier resection of large tumors staged as SCI.

Given the short period of patient follow-up, there were only two relapses in two years. Therefore there is need for further action to claim that this technique has a low recurrence rate, since the recurrence is probably related to incomplete resection of the initial tumor.

\section{BiblIOGRAPHICAL REFERENCES}

1. Tewfik TL, Al Garni MA. Juvenile Nasopharyngeal Angiofibroma. Am J Rhinol Allergy. 2009, 23(1):95-99.

2. Bernal-Sprekelsen M, Alobid I, Guilemany JM. Angiofibroma Juvenil. Acta Otorrinolaringol Esp. 2007, 58(1):84-95.

3. Hervé S, Portier F, Chapot R et al. Fibroma Nasofaríngeo. Encyclopedie Medico-Chirurgicale-Otorrinolaringologia. 2001- E-20-585-A-10.

4. Luiz ACR, Romualdo SLT, Fava AS. Angiofibroma nasofaríngeo: revisão de literatura. Rev. Bras Otorrinolaringol. 2003, 69(3):394-403.

5. Pryor SG, Moore EJ, Kasperbauer JL. Endoscopic versus Traditional Aproaches for Excision of Juvenile Nasopharyngeal Angiofibroma. Laryngoscope. 2005, 115(7):1201-7.

6. Alves FRA, Granato L, Maia MS et al. Acessos Cirúrgicos no Angiofibroma Nasofaríngeo Juvenil - Relato de caso e revisão de literatura. Arq. Int. Otorrinolaringol. 2006, 10(2):162-166.

7. Enepekides DJ. Recent advances in the treatment of juvenile angiofibroma. Current Opnion in Otolaryngology \& Head and Neck Surgery. 2004, 12:495-499.

8. Ferreira LMBM, Gomes EF, Azevedo JF et al. Ressecção Endoscópica de Nasoangiofibroma. Rev. Bras. Otorrinolaring. 2006, 72(4):475-80.

9. Nicolai P, Berlucchi M, Tomenzoli D et al. Endoscopic Surgery for Juvenile Angiofibroma: When and How. Laryngoscope. 2003, 113:775-82.

10. Mendoza MG. Nasoangiofibroma Juvenil Frecuencia, 
Incidencia de acuerdo a grupo sanguineo. An ORL Méx. 2005, 50 (3):17-21.

11. Maurice M, Milad M. Pathogenisis of Juvenile Nasopharyngeal Fibroma (A new concept). The Journal of Laryngology and Otology. 1981, 95:1121-26.

12. Andrade NA, Andrade JSC, Silva PDM et al. Angiofibroma Nasofaríngeo: Revisão dos aspectos genéticos e moleculares. Arq Int ORL. 2008, 12(3):442- 449.

13. Schlauder SM, Knapp C, Steffensen TS et al. Aromatase may play a critical role in the pathogenesis of juvenile nasopharyngeal angiofibroma. Fetal Pediatr Pathol. 2009, 28(5): 232-238.

14. Andrade NA, Pinto JA, Nóbrega MO et al. Exclusively Endoscopic Surgery for Juvenile Nasopharyngeal Angiofibroma. Otolaryngology-Head and Neck Surgery. 2007, 137:492-6.

15. Gusso JL, Souza RP, Rapoport A et al. Nasoangiofibroma Juvenil: concordância interobservadores no estadiamento por tomografia computadorizada. Radiol Bras. 2001, 34(4):207-11.

16. Alborno T, Hofmann Th, Stammberger H et al. Endoscopic Ressection of Juvenile Angiofibroma. Long term results. JRMS. 2005, 12(2):18:24.

17. Onerci TM, Yucel OT, Ogretmenoglu O. Endoscopic Surgery in Treatment of Juvenile Nasopharyngeal angiofibroma. Inter Journal of Pediatric Otorhinolaryngology. 2003, 67:1219-25.

18. Margalit N, Wasserzug O, De -Row A et al. Surgical treatment of juvenile nasopharyngeal angiofibroma with intracranial extension. Clinical article. J Neurosurg Pediatr. 2009, 4(2):113-7.
19. Mair EA, Battiata A, Casler JD. Endoscopic Laser-assisted excision of juvenile nasopharyngeal angiofibromas. Arch Otolaryngol Head Neck Surg. 2003, 129:454-9.

20. Yotakis I, Eleftheriadou A, Davilis D et al. Juvenile Nasopharyngeal Angiofibroma stages I and II: A comparative study of surgical approches. Inter Journal of Pediatric Otorhinolaryngology. 2008, 72:793-800.

21. Mann WJ, Jecker P, Amedee RG. Juvenile Angiofibromas: changing surgical concept over the last 20 years. Laryngoscope. 2004, 114:291-3.

22. Roger G, Ba Huy PT, Froehlich P et al. Exclusively Endoscopic Removal of juvenile Nasopharyngeal Angiofibroma.Trends and Limits. Arch Otolaryngol Head Neck Surg. 2002, 128:928-35.

23. Ardehali MM, Ardestani SHS, Yazdani N et al. Endoscopic approach for excision of juvenile nasopharyngeal angiofibroma: complications and outcomes. Am J Otolaryngol. 2009, 2:335-339.

24. Kennedy DW, Bleier BS, Palmer JN et al. Current Management of juvenile nasopharyngeal angiofibroma: a tertiary center experience 1999-2007. Am J Rhinol \& Allergy. 2009, 23(3):328-330.

25. Huang J, Sacks R, Forer M. Endoscopic resection of juvenile nasopharyngeal angiofibroma. Ann Otol Rhinol Laryngol. 2009, 118(11):764-8.

26. Saylam G, Yücel OT, Sungur A et al. Proliferation, angiogenesis and hormonal markers injuvenile nasopharyngeal angiofibroma. Int J Pediatr. 2006, 70(2):227-34.

27. Solomon DI. Transoral "adenoidectomy" excision of juvenile nasopharyngeal angiofibromas. Ann Otol. Rhinol Laryngol. 2007, 116(4):243-7. 